\title{
Risk Behavior of Onion Farmers in the District Enrekang
}

\author{
Nurhapsa Nurhapsa, ${ }^{1,} \mid$ Arham Arham ${ }^{2}$ | Sitti Nurani Sirajuddin ${ }^{3}$ \\ ${ }^{1}$ Faculty of Agriculture, Animal Science, and Fishery, Universitas Muhammadiyah Parepare \\ ${ }^{2}$ Faculty of Economic, Universitas Muhammadiyah Parepare \\ 3Faculty of Animal Science, Universitas Hasanuddin
}

\begin{abstract}
This study aimed to analyze the risk preference of onion farmers in District Enrekang. A random sample of 75 onion farmers is selected for interviews. The risk preference is analyzed using a model developed by Subal C (2002). The analysis showed that most farmers are not willing to take a risk in the use of various inputs. To increase farmer's willingness, take risks and enhance productivity, strengthening institutions such as farmers' groups or unions as well as enhancing the role of the agricultural extension will be required.
\end{abstract}

Keywords: Risk behaviors, Khumbakar models, Onion farmers

\section{Introduction}

The agricultural sector has significant roles in Indonesia economy. It becomes the as a source of revenue, a promoter of economic growth, and a provider of jobs. Also, the agricultural sector is also an essential provider of raw materials for industry, particularly in the food processing and beverage industry as well as other agro-industries. This sector is also a major pillar in supporting the country's food security.

The superiority of the agricultural sector compared to other sectors in the economy is that it is based on domestic resources. In addition, because there are few imported raw materials or inputs, this sector is relatively more resilient to economic turmoil or monetary and exchange rate changes. The strength of the agricultural sector was proven during the recent monetary crisis, in which this sector becomes the most significant contributor of foreign exchange. The important components or subsectors of agricultural sector are food crops, plantation crops, livestock, forestry, and fishery.

Onion is a significant contributor to the horticulture subdivision of food crops subsector. There are several provinces in Indonesia that produce onion, such as Central Java, East Java, West Java, West Nusa Tenggara, and South Sulawesi. Potential productivity of onion in Indonesia can reach more than 20 tons/ha (Riyanti, 2011).

Enrekang, an onion-producing district in South Sulawesi, has a relatively low productivity, compared to the average national onion production. The low productivity of onion in Enrekang can be explained from how farmers allocate production inputs used in farming. Based on the review of the existing theories and secondary data, the low or even declining productivity of onion in Enrekang might be caused by several factors such as farmer's risk preference in production risks which affect the allocation of production inputs.

*Corresponding author. Email: hapsa faktan@yahoo.co.id 
The risks faced by farmers can be categorized as production risks, price risks, institutional risks, policy risks, and financial risks. According to Sriyadi (2009), the largest source of risks is production risks, such as the risk of pests and diseases that cannot be predicted in advance. Further, Sriyadi states that pests and diseases are triggered by changes in the weather, the bloom of weeds, and poor crop management. Such high production risks have high potential to negatively affect farmer income. The level of risk that attached to potential revenue will strongly affect farmer's decision-making. According to Ellis (1988), farmer's risk preference can be categorized into three groups: (1) farmers who avoid risk (risk averse), (2) farmers who are neutral towards risk (risk neutral), and (3) farmers who dare to take the risk (risk takers).

Subal C (2002) connects production risk, risk selection, and production efficiency, using a model based on Just and Pope, which is developed from the cross-section data of fish producers who cultivate salmon in Norway. The results show that most of the producers are risk-averse. The availability and price of fish foods have the potential to increase the risk of production; however, the use of more skilled human labor can reduce this type of risk. Research conducted by Lawalata (2013) concludes that most of the onion farmers in Bantul are risk-averse, even though onion farming is inherently risky farming. Similar results are shown by Sriyadi, (2009) research on onion and garlic farmers in Karanganyar.

Hence, the purpose of the current study is to analyze Enrekang Onion farmer's risk preference.

\section{Research Methods}

This study is conducted in 2015 in the Anggeraja Subdistrict, which is one of the centers of onion production in Enrekang. A total of 75 onion farmers are randomly selected for an interview. The data used for analysis are primary and secondary data. The data collected are tabulated and analyzed as described below. To analyze the efficiency and farmer's risk preference a model developed by Subal C (2002) is used:

$$
y i=\alpha_{0} \Pi_{j=1}^{7} X_{i j}^{\alpha j}+\beta_{0} \Pi_{j=1}^{7} X_{i j}^{\beta j} \cdot e^{v i}-\gamma_{0} \Pi_{j=1}^{7} X_{i j}^{i j} \cdot e^{u i}
$$

Notes:

$\alpha_{0} \Pi_{j=1}^{7} X_{i j}^{\alpha j}$ is a function of average productivity.

$\beta_{0} \Pi_{j=1}^{7} X_{i j}^{\beta j} \cdot e^{v i}$ is a function of production risk.

$\gamma_{0} \Pi_{j=1}^{7} X_{i j}^{i j} \cdot e^{u i}$ is a function of technical inefficiency, and

$\mathrm{y}_{\mathrm{i}}=$ total onion production $(\mathrm{kg} / \mathrm{ha})$

$\mathrm{X}_{1} \quad=\quad$ the number of seeds used $(\mathrm{kg} / \mathrm{ha})$

$\mathrm{X}_{2}=$ total labor needed (HKSP/ha)

$\mathrm{X}_{3}=$ the amount of urea used $(\mathrm{kg} / \mathrm{ha})$

$\mathrm{X}_{4}=$ the amount of fertilizer used $(\mathrm{kg} / \mathrm{ha})$

$\mathrm{X}_{5}=$ the amount of insecticides used $(\mathrm{kg} / \mathrm{ha})$

$\mathrm{X}_{6}=$ the amount of herbicide used $(\mathrm{kg} / \mathrm{ha})$

$\mathrm{X}_{7}=$ the amount of fungicide used $(\mathrm{kg} / \mathrm{ha})$

$\mathrm{e}^{\mathrm{vi}}=\quad$ error term which shows the uncertainty of the predicted total production assuming i.i.d $(0, \sigma)^{2}$

$\mathrm{e}^{\mathrm{ui}} \quad=\quad$ technical inefficiency assuming i.i.d $(0, \sigma)^{2}$ and $\mathrm{u}>0, \mathrm{u}_{\mathrm{i}}$ are independent of $\mathrm{v}_{\mathrm{i}}$.

The expected sign for each parameter $\alpha_{1}-\alpha_{7}>0 ; \beta_{1}-\beta_{7}<0$ or $\beta_{1}-\beta_{7}>0$; and $\gamma_{1}-\gamma_{7}<0$ or $\gamma_{1}-\gamma_{7}>0$. The model estimation test is performed using maximum likelihood estimation (MLE).

\section{Result \\ Respondents' Profiles}

The respondents' profile (farmers) that will be described in the following section are: (1) the age structure of the farmer respondent sample, (2) education level, (3) experience, (4) the total number of family members, and (5) the area of cultivation land. 
Age

There is an increased ability to work with increasing age, to a certain age point, but which it decreases at some later point in the following ages. Nurhapsa (2013) highlight that age could influence the maturity of thinking and physical ability in managing a business. The age distribution of farmer data of respondents' age can be seen in Table 1. As seen in this table, 98.67\% of the farmers in Anggeraja are mostly in the productive age range, which suggests that onion farming is still a vibrant sector.

Table 1. Respondent's Age

\begin{tabular}{lcc}
\hline \multicolumn{1}{c}{ Age (years old) } & Number & Percentage \\
\hline $15-25$ & 2 & 2.67 \\
$26-35$ & 28 & 37.33 \\
$36-45$ & 29 & 38.67 \\
$46-55$ & 15 & 20.00 \\
56 and older & 1 & 1.33 \\
Total & 75 & 100 \\
\hline
\end{tabular}

\section{Level of Education}

Higher education level helps farmers to understand and accept innovations. Education can also be considered as an investment to improve knowledge, skills, and expertise of the workforce, which will enable them to work more productively, thereby increase their future income. In addition to formal education, non-formal education also helps farmers in developing their business by providing a mean to train useful mindset and technical skills needed by a farmer. The data of respondents' education level can be seen in Table 2. As seen in this table, most of the respondents are graduated from high school (38 people, $50.67 \%)$, while 21 people $(28.00 \%)$ are graduated from elementary school.

Table 2. Respondent's Education Level

\begin{tabular}{lcc}
\hline \multicolumn{1}{c}{ Level of Education } & Number & Percentage \\
\hline Do not attend school & 2 & 2.67 \\
Elementary School & 21 & 28.00 \\
Junior High School & 8 & 10.67 \\
Senior High School & 38 & 50.67 \\
Diploma & 2 & 2.67 \\
Bachelor & 4 & 5.33 \\
Total & 75 & 100 \\
\hline
\end{tabular}

\section{Onion Farming Experience}

Onion farming experience is how long respondents have cultivated onion, stated in the year. Experience is one of the determining factors in the success of farming. There is a tendency that the longer ones manage a farm, they will know more about how to perform farming related jobs, and they tend to adopt the new farming technology. The data on respondents farming experience is presented in Table 3. As can be seen in this table, $94.67 \%$ of farmers have cultivated onion for more than five years.

\section{Number of Family Members}

The number of family members in a household indicates the number of living costs borne by a family. However, a significant number of family members might help the family economy by providing labor that can be asked to perform various activities, including onion farming. The data of respondent's total family members are shown in Table 4 . As can be seen in this table, 57 farmers (76\%) have 4-6 family members in their household. This shows that respondents have a relatively low constraint in term of labor availability. 
Table 3. Respondent's Farming Experience

\begin{tabular}{ccc}
\hline Farming Experience (year) & Number & Percentage \\
\hline $1-5$ & 4 & 5.33 \\
$6-10$ & 20 & 26.67 \\
$11-15$ & 16 & 21.33 \\
$16-20$ & 12 & 16.00 \\
$21-25$ & 11 & 14.67 \\
$>25$ & 12 & 16.00 \\
Total & 75 & 100 \\
\hline
\end{tabular}

Table 4. The Number of Respondent's Family Member

\begin{tabular}{ccc}
\hline $\begin{array}{c}\text { Number of Family Members } \\
\text { (people) }\end{array}$ & Number & Percentage \\
\hline $1-3$ & 12 & 16.00 \\
$4-6$ & 57 & 76.00 \\
$7-10$ & 6 & 8.00 \\
Total & 75 & 100 \\
\hline
\end{tabular}

\section{Area of Farm Land}

The amount of available land is certainly one of the main factors influencing farms production. Here, farm area refers to the land owned by respondents. The average area of land owned by the respondents is 0.74 ha, which rather small and can become an obstacle in increasing farm's production capacity. The distribution of responses can be seen in Table 5 .

Table 5. Farm Area Owned by Respondent

\begin{tabular}{ccc} 
Farm Area Owned by & Number & Percentage \\
Respondents (ha) & & \\
\hline $0.10-0.40$ & 17 & 22.67 \\
$0.41-0,80$ & 38 & 50.67 \\
$0.81-1,20$ & 11 & 14.67 \\
$\geq 1.21$ & 8 & 10.67 \\
Total & 75 & 100 \\
\hline
\end{tabular}

\section{Onion Farmers' Risk Preference}

In farming, farmer's decision to allocate inputs is influenced by their risk preference. The results of the analysis on farmers' risk preference are shown in Table 6 . As seen in this table, the average value of $\theta$ is -0.560 , and the average value of $\lambda$ is 0.551 . These results indicate that most of the farmers show risk-averse behavior. These results are consistent with research conducted by Lawalata, (2013), which shows that most of the onion farmers in Bantul are risk-averse, although onion farming itself is risky farming. Similar results are shown by Sriyadi (2009) in Karanganyar. In contrast, Budiningsih and Pujiharto (2006) show that as many as $76 \%$ of onion farmers in the village of Kiki ran, District Jatibarang, Brebes are risk neutral.

Table 6. Farmer's Risk Preference

\begin{tabular}{lccl}
\hline \multicolumn{1}{c}{ Production Input } & Average $\theta$ & Average $\lambda$ & Risk Preference \\
\hline Seed & 0.114 & 0.474 & Risk Taker \\
Labor & -0.060 & 0.435 & Risk Averse \\
Fertilizer Urea & 0.034 & 0.484 & Risk Taker \\
Fertilizer Matahari & -0.105 & 0.432 & Risk Averse \\
Insecticides & -0.088 & 0.278 & Risk Averse \\
Herbicides & -3.793 & 1.302 & Risk Averse \\
Fungicides & -0.020 & 0.455 & Risk Averse \\
Average & -0.560 & 0.551 & Risk Averse \\
\hline
\end{tabular}


Seeds and urea fertilizer are the risks that onion farmers usually take. This means that onion farmers behave toward risk in allocating inputs of seeds and urea fertilizer. On average, onion farmers need 988 kilograms seed per hectare. A number of onion seeds used per hectare depend on the type/variety of the onion, seed size, and desired plant spacing. Regarding urea, in average farmer uses as much as 214.3 kilograms urea fertilizer per hectare. The amount of urea used does not match with the recommended dose, an average of 187 kilograms per hectare.

In contrast, farmers are avoiding the risk in labor input, additional fertilizers, insecticides, herbicides, and fungicides. The average amount of labor (Equal Employment Day Men/HKSP) used by sampled onion farmers, from land preparation to post-harvest is 125.8 HKSP. A similar result is also found in Nurhapsa (2013) study which finds that Enrekang farmers who grew kalosi and canola potatoes are risks-averse in terms labor inputs. Also, research conducted by Fariyanti (2008) shows that potato and cabbage farmers prefer risk-averse attitude toward labor input.

Onion farmers in our sample in Anggeraja generally used solar fertilizer, which is a substitution for $\mathrm{KCl}$, as additional fertilizer. Onion farmers were risk-averse against solar fertilizer inputs, i.e., reluctant or afraid to allocate solar fertilizer inputs. The average use of potassium fertilizers is 174.2 kilogram per hectare; the use of $\mathrm{KCl}$ is still below the recommended dosage, which is 220 kilograms per hectare.

Onion farmers are risk averse regarding insecticides input. The average input use of insecticides in the sample is 25.9 liters per hectare. This result is consistent with research conducted by Nurhapsa, (2013), which shows that farmers who grow kalosi and canola potatoes prefer risk aversion on the input of insecticides.

Table 6 also shows that farmers are risk-averse to herbicide and fungicide inputs. Thus the use of both inputs is low. The average use of herbicides in onion farming is 4.3 liters per hectare; the average for fungicides is 116.6 kilograms per hectare. The dosage of fungicide depends on the type of fungicide used. The results of this research differ from research conducted by Nurhapsa, (2013), who find that the behavior of farmers who grow canola and kalosi potatoes are risk-takers regarding fungicide input.

\section{Conclusion}

Onion farmers in district Anggeraja are mostly graduated from the high school. They have average farmland of 0.73 hectares and have been farming for over than five years. Most of the onion farmers in district Anggeraja Enrekang are risk-averse. The result from this study encourage farmers to take more risks in order to boost productivity and profits. Therefore, it might be necessary to increase the role of farmer groups (GAPOKTANI) and the role of agricultural extension.

\section{References}

Budiningsih, S. and P. Pujiharto. (2006), "Analisis Risiko Usahatani Bawang Merah di Desa Klikiran Kecamatan Jatibarang Kabupaten Brebes”, Agritech, Vol. VIII No. 1, pp. 127-143.

Ellis, F. (1988), Peasant Economics: Farm Household and Agricultural Development, Cambridge University Press, Cambridge.

Fariyanti, A. (2008), Perilaku Ekonomi Rumahtangga Petani Sayuran Dalam Menghadapi Risiko Produksi Dan Harga Produk Di Kecamatan Pangalengan Kabupaten Bandung. Unpublished Doctorate Dissertation, Institut Pertanian Bogor, Bogor.

Lawalata, M. (2013), Analisis Efisensi Relatif Dan Perilaku Petani Terhadap Risiko Usahatani Bawang Merah Di Kabupaten Bantul, Unpublished Undergraduate Dissertation, Universitas Gadjah Mada, Yogyakarta.

Nurhapsa, N. (2013), Analisis Efisiensi Teknis Dan Perilaku Risiko Petani Serta Pengaruhnya Terhadap Penerapan Varitas Unggul Pada Usahatani Kentang Di Kabupaten Enrekang Provinsi Sulawesi Selatan, Unpublished Postgraduate School, Institut Pertanian Bogor, Bogor.

Riyanti, L. (2011), Analisis Efisiensi Ekonomi Penggunaan Faktor-Faktor Produksi Pada Usahatani Bawang Merah Varietas Bima Di Kabupaten Brebes, Unpublished Undergraduate Dissertation, Universitas Sebelas Maret, Surakarta.

Sriyadi, S. (2009), Efisiensi Relatif Dan Perilaku Petani Terhadap Risiko Usahatani Bawang Merah Dan Bawang Putih Di Kabupate Karanganyar, Unpublished Undergraduate Dissertation, Universitas Gadjah Mada, Yogyakarta.

Subal, K. (2002), "Specification and Estimation of Production Risk, Risk preferences and Technical Efficiency", American Journal of Agricultural Economics, Vol. 84 No. 1, pp. 8-22. 